\title{
Exploring Indonesian English Teachers' Perspectives toward the Use of Translation in English Language Teaching (ELT) Classroom
}

\author{
Nizar Saputra \\ ${ }^{1}$ Teaching English to Speakers of Other Languages, Faculty of Education, Monash University, Melbourne, 3168, Australia \\ a nizarsaputra5@gmail.com \\ ${ }^{*}$ Corresponding Author \\ Whatsapp Number [+61423958557]
}

How to Cite: Saputra, N. (2020). Exploring Indonesia English teachers' perspectives toward the use of translation in English language teaching (ELT) classroom. International Journal for Educational and Vocational Studies,2(3), 401-405. DOI: https://doi.org/10.29103/ijevs.v2i3.2210

\section{ARTICLE HISTORY}

Received: 24 January 2020

Revised: 28 February 2020

Accepted: 8 March 2020

\section{KEYWORDS}

Translation;

TILT;

English Language Teaching (ELT);

First language (L1);

Second Language (SL);

Foreign Language (FL);

\section{ABSTRACT}

This study aims to investigate Indonesian teachers' perspectives of translation or first language used in ELT classrooms as well as to find out the teachers' strategies on how to incorporate translation as their pedagogical tool. This research is applied in a case study methodology, in which the researcher interviewed three English teachers in Indonesia to explore their perspectives. The raw data was analysed by using thematic analysis to find the emerging themes of the interview data which led to the result of this qualitative research. The result of the finding indicates that the teachers mostly have positive perceptions about TILT (translation in language teaching). Most participants believed that when translation use selectively, it can help students with foreign language learning, promote students' metalinguistic awareness, function as a thinking tool, mediate social interaction, and function as social mediation. Additionally, the strategies of TILT applied by the teachers in this study entail explaining difficult concepts and grammar, avoiding chunks of word translation, and nurturing students' critical thinking and problem-solving skills. It is suggested that if translation is integrated into language teaching, it should be used selectively as a pedagogical tool to support students' learning.

This is an open access article under the CC-BY-SA license.

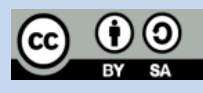

\section{INTRODUCTION}

The use of translation which refers to the use of first language (L1) as a pedagogical tool has become controversial in the field of teaching English to speakers of other languages (TESOL). This debate has been ongoing since the initial emergence of contrastive analysis developed by Robert Lado ( as cited in Cook, 2001) in his early work 'Linguistics Across Cultures' in 1957. The contrastive analysis hypothesis (CAH) states that L1 use in language teaching can be a significant obstacle to mastering foreign language (FL) or second language (SL) (Ali, 2012). According to Leung (2005), contrastive analysis was constructed based on behaviourist theory. This theory highlights that how translation in language teaching (TILT) can lead to language transfer or language interference. Leung (2005) explains that language interference refers to a process in which prior learning is transferred into a new learning situation. Based on this perspective, the use of translation as a pedagogical tool has been ignored, and target language use only is encouraged in FL or SL learning. For example, Auerbach (1993) highlighted that the practice of an 'English Only' movement in the English as a second language (ESL) classroom in the United States was the evidence of target language use as the only acceptable medium of communication. As a result of this, many English instructors today, including those in Indonesia, may uphold the idea that English is the only acceptable pedagogical tool in the English language teaching (ELT) classroom.

Although the use of the target language is preferable in an ESL or English as a Foreign Language (EFL) classroom, translation in language teaching has been a common practice for many language learners and teachers, including those in Indonesia. Leung (2005) argues that translation has been used by many language learners to support their FL learning, such as consulting a bilingual dictionary and as a code switch when the students communicate with their friends, or instructors, in the classroom. This has resulted in the generation of a discrepancy between what is happening and what should be happening in FL teaching. This gap has led many researchers and experts in the field to conduct more research to investigate the role of the mother tongue in FL or SL learning. Much contemporary research has 
challenged opponents of banning translation in language teaching, many of which highlight positive benefits of translation used in language teaching. For example, a study conducted by Alvarez (2014) shows that the translation used as a pedagogical tool has an essential role in assisting students' learning by maintaining their' motivational, affective, attitudinal, and cognitive aspects when it is used selectively. Similarly, Calis and Dikilitas (2012) indicate that the most students have had an affirmative stance on translation use, as it assists them in reading comprehension and memorising English vocabulary. Guerra's (2014) also highlights that the application of TILT can facilitate deeper comprehension, and so improve students' metalinguistic awareness, help them to express their ideas faster, and develop their cultural knowledge.

Although there have been many studies supporting TILT, Ali (2012) explains that many English instructors still worry and are unsure about the use of pedagogical translation. Similarly, in Indonesia, many English practitioners and EFL students have different perspectives on the use of translation or their first language in the classroom. Some teachers allow its use to support students' learning, while others prohibit it because of their negative view of translation (Resmini, 2019). Therefore, this research aims to investigate the role of translation in English language teaching and to find out the strategies in integrating TILT.

\section{METHODS}

\subsection{Research Method}

This research is based on qualitative research in which the researcher applied a case study methodology to find out teachers' perspectives as well as strategies used on L1 or TILT integration. A semi-structured interview was used as an instrument to collect the data. The interview was conducted on the phone and recorded before its transcribed, coded, and analysed.

\subsection{Theoretical Framework}

This research was framed through Vygotsky works on ZPD (zone of proximal development). According to Vygotsky (1978, p. 87), the ZPD refers to "the distance between the actual developmental level as determined by independent problem solving and the level of potential development as determined through problem solving under adult guidance or in collaboration with more capable peers." Leung (2005) and Lantolf (2000) clarify this definition as the discrepancy between what a person can perform when working alone and what the same person can achieve when working with assistance from cultural artefacts or someone else. Linking this explanation to TILT integration, translation as a cultural artefact could be recognised as assistance to support students with language learning development or, in other words, L1 or translation acts as a scaffolding learning in target language learning. Leung (2005) developed a framework of L1 role in language teaching based on this Vygotsky's perspective. According to Leung, there are several roles of TILT which entail of mediating language learning, facilitating metalinguistic awareness, functioning as private speech (cognitive tool), a tool for thinking, and acting as social interaction and mediation.

\subsection{Participants}

The participants of this research consist of three English teachers who have been teaching English in secondary school for more than five years. These participants were contacted and agreed to voluntarily participate in this research after Ethical approval obtain form the Monash University Human Research Ethics Committee (MUHREC).

\subsection{Data Analysis}

The recorded interview data gained from this research was transcribed, coded, and analysed using thematic analysis. The recurring themes consist of teachers' perspective about TILT, teachers' perspective of language interference, and strategies teachers use in incorporating TILT.

\section{RESULTS AND DISCUSSIONS}

\subsection{Teachers' perspective about TILT}

Overall, the participants' perceptions were in line with Vygotsky's framework developed by Leung (2005). For example, the three participants in this research agreed that TILT could facilitate their English language learning by saving more teaching time and providing a comprehensible lesson to the students. This finding is relevant to the first main point of the theoretical framework of this study in which TILT facilitates FL learning. Leung (2005) highlights L1 promotes foreign language learning by providing a comprehensible lesson to the students. Similarly, this idea also highlighted in many studies (Leung ,2005; Ali, 2012; Guerra, 2014; and Alvarez, 2014). Littlewood and Yu's (2011), for instance, shows that SL teachers' use of translation can ensure students' understanding and save teaching time. Therefore, it is likely that L1 use does facilitate English language teaching in Indonesia by providing ELT teachers with teaching time efficiency and providing a comprehensible lesson to the students.

Furthermore, the all participants noted that translation can promote students' metalinguistic awareness. This finding is supported by Mohebbi and Alavi (2014), who share a similar view with Ali (2012), that translation used as a pedagogical tool can effectively maintain and support students' comprehension of grammar, offer target language cultural production, and ease the introduction of new vocabulary. However, one of the participants also noted that TILT could lead students to feel lazy as students felt less challenged in the classroom due to translation was provided. This perception reflects Yavuz's (2012) who shows that one of his participants mentioned that L1 use could make students feel lazy since the students were not challenged in terms of cognitive and analytic understanding of the target language. In contrast, this perception seems to be weak as most of the participants in the study stated the 
opposite view. Therefore, although to some extend it may result in leading tedious learning environment, Alvarez (2014) argue that TILT can also influence students' motivation to learn an FL as it makes students feel more comfortable.

Moreover, the findings of this research also indicate that TILT could function as the students' self-regulated talk, which is a cognitive tool in learning EFL (English as a foreign language). According to Leung (2005), L1 use can scaffold students' learning by providing them with an opportunity to talk to themselves as a thinking tool before performing in the target language. Leung (2005) clarifies this by saying as they use their inner speech or self-talk, language students can monitor and plan their target language production. A similar point is made by Centeno-Cortes and Jimenez (2004), indicating that TILT plays a vital role in the reasoning process of acquiring the target language. This finding also supports Otha's (2001) idea, highlighting that Japanese students' use of their mother tongue as their inner speech contributes to their English production in class. Accordingly, based on the findings and discussed literature, it appears that TILT can indeed function as a cognitive tool by providing students with a self-talk strategy before producing their target language.

In addition, the finding also confirms that TILT can function as a tool for social interaction in the ELT class. This finding is relevant to much SL and FL learning research (Cook, 2001; Leung, 2005; Liao, 2006; Calis and Dikilitas, 2012; Guerra, 2014). For instance, Pan and Pan (2012) say that by using translation in target language learning, it allows the language learners to build a meaningful conversation with their peers, which also allows them to help each other during group discussions and ask questions of the teacher. Similarly, Ali (2012) clarifies that with the help of the L1, target language learners can help peers who might be incapable of understanding the lesson. This assistance could help the language learners to build their understanding of the lesson and appears to develop their cognitive and language development. Lantolf and Thorne (2007) indicate that in Vygotsky's perspective, learning and cognitive development, which also involves language, occurs as a result of social interaction. Therefore, allowing appropriate use of translation in the EFL class could contribute to developing the students' social interaction by enhancing their language learning and cognitive development.

Lastly, the overall data also shows that TILT can function as social mediation for language learners. This finding is in line with Calis and Dikilitas (2012), who say that through translation use, language learners feel more comfortable learning the target language as their learning anxiety and overload is reduced by translation. Mohebbi and Alavi (2014) also state that language learners could engage actively during the learning process due to the application of translation as the students feel less worried. In terms of the theoretical framework of this research, the finding confirms that in the ZPD concept, with the scaffold of the L1, students feel less anxiety and less learning overload due to their understanding of the lesson, which results in the students feeling more comfortable learning the target language (Leung, 2005). Drawing on this finding, the literature review, and theoretical framework, translation use can contribute to reducing students learning anxiety, which could result in students feeling more comfortable learning the FL.

However, it is currently unclear whether or not translation use can lead students to feel more nervous due to feeling intimidated by other students' English skills as this issue barely addressed in the role of L1 in language teaching. However, this issue appears to be related to phycological factors that hinder students from speaking English in the class. Juhana (2012) highlights several phycological factors that could hinder students from speaking English in the Indonesian context; these factors entail shyness, anxiety, fear of generating mistakes, and lack of confidence and motivation. Juhana (2012) explains that these factors are commonly caused by the students' fear of being laughed by their friends. Juhana (2012) suggested that the remedy for these issues is to motivate students to be more confident in speaking English. Therefore, it is likely that the translation used cannot be associated as the main factor that causes psychological issues since many works of literature noted above indicate that TILT or L1 can function as social mediation.

\subsection{Teachers' perspectives about language interference}

The findings above reveal that the three participants do not blame translation as the source of language interference. For example, Participant $\mathrm{C}$ said that language interference was associated with his students' ignorance of comparing the two language systems. This finding is related to the idea proposed by Newmark (1966), who argues that negative transfer is not the result of L1 interference; instead, it is the effect of the learners' ignorance. Newmark (1966) clarifies that the act of comparing and using prior L1 knowledge to produce the target language output can be considered as an act of ignorance, and the remedy for this ignorance is merely learning. From the findings, Participant $\mathrm{A}$ and Participant $\mathrm{C}$ encouraged their students not to use the L1 system while producing the English output. They suggested that the students should follow the target language rule in generating the target language output. This finding confirms Corder's (1992) research that language interference or language error will not happen if students acquire the target language structures before creating English output.

Drawing on the perceptions of Participant A and Participant B in this theme shows that translation cannot be solely blamed for language interference. This is supported by Ali (2012), who states that most errors produced in the target language by language learners are not the result of $\mathrm{L} 1$ interference, and instead are the result of a developmental error. Ali (2012) clarifies developmental errors as errors that naturally occur during the process of target language learning regardless of students' L1. Reflecting on this explanation and the participants' perceptions, it can be argued that the L1 or translation used in the EFL class cannot be judged as the main factor for language interference; instead, TILT should be considered as a learning tool to support FL learning. It is suggested based on this perspective that TILT should be used appropriately to support EFL learning to avoid language interference. 


\subsection{Teachers' strategies on incorporating TILT}

The three teacher participants in this study did not have specific guidelines on how to integrate TILT. This perspective confirmed Alvarez's (2014) idea that there are no such guidelines on how to integrate translation into FL or SL learning. From this perspective and finding, it can be assumed that the amount of translation or L1 use in language teaching depends on the students' language proficiency. However, Ali (2012), shows some approaches for TILT incorporation which include cognitive, memory, affective, social, and compensation approaches. Cook (2013) proposed several approaches for L1 or translation use, which include checking and conveying meaning, explaining grammar, organising tasks, maintaining discipline, organising class, and maintaining students' interactions. Ali's (2012) and Cook's (2013) ideas apply to this theme in which the participants used TILT to explain difficult concepts such as grammar (cognitive strategies), to ensure the students' understanding (social and compensation strategy), and teaching vocabularies (memory strategy).

Furthermore, the finding that TILT facilitates students' critical thinking and problem-solving builds upon existing knowledge that Leung (2005) discussed in his study. Leung (2005) argues that L1 can be used as a thinking tool to solve a problem in second or target language learning. Leung (2005) explains that through the incorporation of TILT, language learners can organise and restructure perceptions related to intention and goal, which could result in solving problems in the target language. This idea also reflects Vygotsky's perspective of how language can act as a self-regulatory tool that solves the problem by incorporating the students' metacognition functions, which entails planning, voluntary attention, logical memory, evaluation, and problem solving (Leung, 2005).

\section{CONCLUSION}

Overall, the results of this research show that most of the participants have positive perceptions of translation in their language teaching. The findings indicate that translation in the ELT class could contribute to facilitate English learning, promoting the students' sense of metalinguistic awareness, functioning as private speech, and facilitating social interaction and social mediation. In terms of strategies, the teacher participants apply translation selectively to help their students with difficult concepts, to explain grammar, to avoid chunks of word translation, and to develop the students' critical thinking and problem-solving skills. In terms of language interference, the three teachers do not blame translation as the main factor of language interference; instead, this is due to the unselective use of translation and the students' ignorance. Therefore, if translation is integrated into language teaching, it should be used selectively as a pedagogical tool to support students' learning.

\section{REFERENCES}

Ali, S. (2012). Integrating translation into task-based activities - A new direction for ESL teachers. Language in India, 12(8), 429-440. Retrieved from: https:// pdfs.semanticscholar.org/72ba/cff44e584eeed9b9f94727 d600be71ace280.pdf

Alvarez, C. L. F. (2014). Selective use of the mother tongue to enhance students' English learning processes...beyond the same assumptions. Profile Issues in Teachers' Professional Development, 16(1), 137-151. doi:10.15446/profile.v16n1.38661

Auerbach, E. (1993) Re-examining English only in the ESL classroom. TESOL Quarterly, 27(1), 9-32. doi:10.2307/3586949

Calis, E., \& Dikilitas, K. (2012). The use of translation in EFL classes as L2 learning practice. Procedia - Social and Behavioral Sciences, 46(12), 5079-5084.

doi:10.1016/j.sbspro.2012.06.389

Centeno-Cortes, B. and Jimenez, A.F.J. (2004) Problem-solving tasks in a foreign language: the importance of the LI in private verbal thinking. International Journal of Applied Linguistics, 14(1). 7-35. Retrieved from:

https://onlinelibrary.wiley.com/doi/abs/10.1111/j.1473-4 192.2004.00052.

Cook, V. (2001). Using the first language in the classroom. Canadian Modern Language Review, 57(3), 402-423. doi: 10.3138/cmlr.57.3.402

Cook, V. (2013). Second language learning and language teaching ( $4^{\text {th }}$ ed.). New York: Routledge.

Guerra, A. F. (2014). The usefulness of translation in foreign language learning: students' attitudes. International Journal of English Language and Translation Studies, 2(1), 153-170. Retrieved from http://repositori.uji.es/xmlui/bitstream/handle/

10234/134505/62499.pdf

Juhana, J. (2012). Psychological factors that hinder students from speaking in English class (A case study in a senior high school in South Tangerang, Banten, Indonesia). Journal of Education and Practice, 3(12), 100-110. Retrieved from: https://pdfs.semantic

scholar.org/d15d/6f0996ba052be768e366ea4a18d18fe7e903 .pdf

Kelleher, M. (2013). Overcoming the first language taboo to enhance learning a foreign language. Procedia-Social and Behavioral Sciences,93, 2037-2042. doi: 10.1016/j.sbspro.2013.10.161

Lantolf, J. P., \& Thorne, S. L. (2007). Sociocultural theory and second language learning. In B. Van Patten \& J. Williams, Theories in second language acquisition: an introduction. (pp. 197-221). Mahwah: Lawrence Erlbaum.

Leung, K. K. (2005). The role of the first language in second language learning for adult learners: a Vygotskian perspective (Doctoral dissertation). University of Technology, Sydney, Australia.

Liao, P. (2006). EFL learners' beliefs about and strategy use of translation in English learning. RELC, 37(2), 191-215. 
doi: 10.1177/0033688206067428

Littlewood, W., \& Yu, B. (2011). First language and target language in the foreign language classroom. Language Teaching, 44(1), 64-77.

doi: $10.1017 / \mathrm{S} 0261444809990310$

Mohebbi, H., \& Alavi, S.,H. (2014). Teachers' first language use in second language learning classroom context: A questionnaire-based study. Bellaterra Journal of Teaching \& Learning Language \& Literature, 7(4). 57-73. Retrieved from:

https://revistes.uab.cat/jtl3/article/view/v7-n4-mohebbialaviMohammad

Newmark, L. (1966) How not to interfere with language learning. International Journal of American Linguistics. 32(1). 77-83.

Ohta, A. S. (2001). Second language acquisition processes in the classroom: Learning Japanese. London: Routledge.

Pan, Y. C., \& Pan, Y. C. (2012). The use of translation in the EFL classroom. Philippine ESL Journal, 9, 4-23. Retrieved from:

https://www.philippine-esl-journal.com/wp-content/uplo ads/2014/01/V9-A1.pdf

Resmini, S. (2019). EFL students' perception toward the use of Bahasa Indonesia in an English classroom. Journal of English Language Teaching in Indonesia, 7(1), 12-22. Retrieved from:http://e-journal.stkipsiliwangi.ac.id/index.php/elti n/article/view/1211/692

Vygotsky, L.S. (1978) Mind in Society: the development of higher psychological processes. Cambridge: Harvard University Press.

Yavuz, F. (2012). The attitudes of English teachers about the use of L1 in the teaching of L2. Procedia - Social and Behavioral Sciences, 46, 4339-4344.

doi: 10.1016/j.sbspro.2012.06.251 